\title{
Meteorological and agricultural drought indices used in drought monitoring in Poland: a review
}

\author{
Leszek Łabędzki, Bogdan Bąk \\ Institute of Technology and Life Science, Kujawsko-Pomorski Research Centre, Glinki 60, 85-174 Bydgoszcz, Poland, \\ e-mail: l.labedzki@itp.edu.pl,b.bak@itp.edu.pl
}

\begin{abstract}
In the article, a brief review is presented of the definition of meteorological and agricultural droughts, drought indices and the operational systems of monitoring droughts in Poland. Drought is a widespread and frequent disaster which occurs more often within humid climate zones. Meteorological drought is the result of deficiencies in precipitation. Agricultural drought is an effect of various characteristics of meteorological and hydrological drought in agriculture comprising the reduction of evapotranspiration, soil water deficits, and reduced crop yield. Drought indicators are the common measures for drought assessment. The paper contains an inventory of drought measures (indicators) that are applied to evaluate meteorological and agricultural drought in Poland. For meteorological drought monitoring and the assessment of its intensity, four different indices have been used in Poland: relative precipitation index $(R P I)$, effective drought index $(E D I)$, standardised precipitation index $(S P I)$ and climatic water balance $(C W B)$. Agricultural drought is monitored by soil moisture index $(S M I)$, agricultural drought index $(C D I)$ and the potential reduction of final yield (yield reduction ratio $Y R$ ). The working drought monitoring systems give information for the whole country or for a specific region but they are directed to some specific drought analyses. Four different drought monitoring systems have been under operation in Poland since 2005. The Institute of Meteorology and Water Management (IMGW) conducts the system called "POSUCH@”. The Institute of Soil Science and Plant Cultivation conducts the agricultural drought monitoring system. The Institute of Technology and Life Sciences (ITP) has developed two systems: the regional drought monitoring system in the Kujawy region and the nationwide system of monitoring and forecasting water deficit and surplus in agriculture.
\end{abstract}

Keywords: drought indices, meteorological drought, agricultural drought, monitoring, operational system

Submitted 20 March 2014, revised 21 November 2014, accepted 25 November 2014

\section{Introduction}

According to recent studies and investigations, droughts should be defined as a natural but temporary imbalance of water availability, consisting of a persistent lower-thanaverage precipitation, and resulting in dimi-nished water resources availability (Pereira et al. 2002; Paulo, Pereira 2006). Generally the definitions state that drought is due to the breakdown of the rainfall regime. Meteorological drought is most often expressed in terms of rainfall in relation to some average amount and the duration of the dry period and can be defined as a period with a lack of precipitation or with rainfall lower than average, lasting sufficiently to cause hydrological and agricultural hazards.

The negative effect of meteorological droughts is complex and can be observed in various branches of the national economy. It is particularly visible in agriculture. The effect in agriculture is differentiated and depends on the duration and intensity of meteorological drought before and during an agricultural drought. Droughts negatively affect crops, but the effect varies for various plants, soils and geographic regions. A crop decrease is a final effect of agricultural drought and depends largely on the duration and intensity of the drought. Autumn and early spring droughts usually cause a decrease in winter crops while spring droughts cause a decrease in spring crops, the first hay cut and pasture efficiency. Summer droughts usually negatively affect potato crops, the second hay cut and field fodder crops.

Meteorological drought is expressed solely on the basis of the degree of dryness (usually related to the departure of rainfall from the average) and duration of a dry period. Agricultural drought links various characteristics of meteorological drought to agricultural impacts, focusing on precipitation shortages, differences between actual and potential evapotranspiration, soil water deficits etc. Any realistic definition of agricultural drought should account for the variable susceptibility of crops at different stages of crop development. Most commonly agricultural drought is defined as soil water deficit of a particular crop at a particular time period or moment, affecting crop yield and leading to a significant decline in crop yield. 
The object of the paper is meteorological and agricultural drought defined in this way. The article reviews the measures for meteorological and agricultural drought used in drought monitoring systems operating in Poland.

\section{Meteorological drought}

Many indices and methods have been developed and are used to identify and determine the intensity of meteorological drought (Vogt, Somma 2000). Among them the standardised precipitation index SPI has received special attention in recent years since its introduction by McKee et al. (1993, 1995). It was applied to the analysis of regional droughts in Portugal (Paulo et al. 2002; Alfonso 2005; Paulo, Pereira 2006;), in Crete (Tsakiris, Vangelis 2004), in Sicily (Bonaccorso et al. 2003), in Hungary (Szalai, Szinell 2000; Szalai et al. 2000) and for the whole of Europe (Lloyd-Hughes, Saunders 2002). It is widely recommended as a very simple and objective measure of meteorological drought (Vermes 1998; Vermes et al. 2000; U.S. National Drought... 2014).

For meteorological drought monitoring and the assessment of its intensity four different indices have been used in Poland: relative precipitation index $(R P I)$, effective drought index $(E D I)$, standardised precipitation index $(S P I)$ and climatic water balance $(C W B)$. The RPI, EDI and $S P I$ calculation is based on long-term (at least 30year) precipitation records.

1. Relative Precipitation Index $(R P I)$ is the ratio of precipitation sum for the given period $P$ and the long-term average for the same period $\bar{P}$ expressed in percent :

$$
R P I=\frac{P}{\bar{P}} \cdot 100 \%
$$

According to Kaczorowska (1962) and Tomaszewska (1997) three classes of dry periods in terms of precipitation conditions are distinguished (Tab. 1).

Table 1. Classes of dry periods (according to Kaczorowska (1962), Tomaszewska (1994))

\begin{tabular}{|l|c|c|}
\hline \multirow{2}{*}{\multicolumn{1}{|c}{ Period }} & \multicolumn{2}{|c|}{ Percent of the average in: } \\
\cline { 2 - 3 } & month & quarter, year \\
\hline Extremely dry & $0-24.9$ & $0-49.9$ \\
\hline Very dry & $25.0-49.9$ & $50.0-74.9$ \\
\hline Dry & $50.0-74.9$ & $75.0-89.9$ \\
\hline Average & $75.0-125.9$ & $90.0-110.9$ \\
\hline
\end{tabular}

2. Effective Drought Index (EDI) is a measure of precipitation needed for a return to normal conditions (To- karczyk, Szalińska 2013). The concept of the EDI is a standardised daily difference between weighted precipitation accumulation over a defined preceding period and its multiyear mean value for each calendar day. It is calculated with a daily time step. EDI values are standardised, which allows for the comparison of drought severity at different locations regardless of climatic differences among them. The 2-category classification (Tab. 2) of dry periods is used in the drought monitoring system called "POSUCH@" conducted by the Institute of Meteorology and Water Management (IMGW) (http://posucha.imgw.pl/).

Table 2. Classification of EDI values and precipitation conditions, according to http://posucha.imgw.pl/

\begin{tabular}{|c|c|}
\hline$E D I$ & Precipitation conditions \\
\hline$(0.7 \div-0.7)$ & normal \\
\hline$[-0.7 \div-1.5)$ & dry \\
\hline$\leq-1.5$ & very dry \\
\hline
\end{tabular}

3. Standardised Precipitation Index $(S P I)$ is a standardised deviation of precipitation in a particular period from the median long-term value of this period (McKee et al. 1993, 1995). SPI is calculated for each calendar month at 1-, 2-, 3-, 6-, 12-, 24-, 36- and 48-month time scales using long-term series of precipitation measurements at different meteorological stations all over the country. SPI values for periods longer than 1 month are calculated for moving totals of precipitation. For each month of the calendar year a new series is created with elements equal to corresponding precipitation moving sums. For example, the 3-month SPI calculated for June 2013 utilised the precipitation total of April 2013 through June 2013 in order to calculate the index. Likewise the 12-month SPI for June 2013 utilised the precipitation total for July 2012 through June 2013. Thus, SPI values describe meteorological drought at the end of a month, caused by a deviation of precipitation during 1-, 2-, 3-, 6-, 12-, 24-, 36- and 48-month time periods in relation to the median value (values with $50 \%$ probability).

SPI is calculated using the normalization method. Precipitation is a random variable with a lower limit and often positive asymmetry, and does not conform to the normal distribution. Most often periodical (10-day, monthly or annual) sums of precipitation conform to the gamma distribution and therefore the precipitation sequence is normalised with the transformation function $f(P)$ :

$$
f(P)=u=\sqrt[3]{x}
$$

where: $x$ - the element of precipitation sequence.

Values of the SPI for a given $P$ are calculated from the equation: 


$$
S P I=\frac{f(P)-\bar{u}}{d_{u}}
$$

where: $S P I$ - standardised precipitation index, $f(P)$ - transformed sum of precipitation, $\bar{u}$ - mean value of the normalised precipitation sequence, $d_{u}-$ standard deviation of the normalised precipitation sequence.

The negative values of SPI are compared with the boundaries of different classes of drought. There are many classifications used by different authors. Originally McKee et al. (1993) distinguished 4 categories of drought: mild, moderate, severe and extreme, with the threshold value of $S P I$ for the mild drought category equal to $S P I=0$ (tab. 3). Agnew (2000) writes that in this classification all negative values of SPI are taken to indicate the occurrence of drought - this means that for $50 \%$ of the time, drought is in occurrence. He concluded that this was not rational and suggested alternative, more rational thresholds. According to Vermes (1998) three categories are proposed, with the first class starting at $S P I=-1$. The class of mild drought $(-1<S P I<0)$ was aggregated with the slightly wet class $(0 \leq S P I \leq 1)$ into the near normal class. Because of the great variability of precipitation in Poland, modification of SPI in the scope of the threshold of the moderate drought class was proposed (Łabędzki 2007). This was an attempt to apply this index to detect periods of mild drought, especially in shorter periods, e.g. months. According to this the threshold value of the first class of drought was changed to $S P I=-0.5$ (Tab. 4). Nowadays two classifications are used in Poland: the 3-category classification according to Łabędzki (2007) in the drought monitoring system called "POSUCH@" conducted by the Institute of Meteorology and Water Management (IMGW) (http://posucha.imgw.pl)

Table 3. Classification of the SPI values and meteorological drought category

\begin{tabular}{|c|c|c|}
\hline \multirow{2}{*}{ SPI } & \multicolumn{2}{|c|}{$\begin{array}{r}\text { Meteorological drought category } \\
\text { according to }\end{array}$} \\
\cline { 2 - 3 } & McKee (1993) & Vermes (1998) \\
\hline 0 to -0.99 & mild drought & near normal \\
\hline-1.00 to -1.49 & moderate drought & moderate drought \\
\hline-1.50 to -1.99 & severe drought & severe drought \\
\hline$\leq-2.00$ & extreme drought & extreme drought \\
\hline
\end{tabular}

Table 4. Classification of SPI values and meteorological drought category, according to Łabędzki (2007)

\begin{tabular}{|c|c|}
\hline SPI & Meteorological drought category \\
\hline 0.50 to -0.49 & normal \\
\hline-0.50 to -1.49 & moderate drought \\
\hline-1.50 to -1.99 & severe drought \\
\hline$\leq-2.00$ & extreme drought \\
\hline
\end{tabular}

and the 4-category classification as shown in Table 5 used in the system of "Monitoring and forecasting water deficit and surplus in agriculture" (http://agrometeo.itp.edu. pl) conducted by the Institute of Technology and Life Sciences (ITP).

Table 5. Classification of SPI values and meteorological drought category used by ITP (www.agrometeo.itp.edu.pl)

\begin{tabular}{|c|c|}
\hline SPI & Meteorological drought category \\
\hline 0.50 to -0.49 & normal \\
\hline-0.50 to -1.00 & mild drought \\
\hline-1.00 to -1.49 & moderate drought \\
\hline-1.50 to -1.99 & severe drought \\
\hline$\leq-2.00$ & extreme drought \\
\hline
\end{tabular}

4. Climatic Water Balance $(C W B)$ is the other indicator used in Poland for meteorological drought monitoring and the assessment of its intensity. Meteorological drought is a phenomenon manifested by precipitation deficit in relation to average values. It is the most common approach in the defining and identification of this type of drought. However, a broader approach to this phenomenon is needed. A parameter which provides a more complex characteristic of meteorological drought is climatic water balance. It describes moisture conditions determined by atmospheric precipitation as water input, and evaporation as water loss. Climatic water balance, therefore, is a comprehensive indicator which includes all basic meteorological factors that are decisive for meteorological drought generation, i.e. precipitation and evaporation. A balance of precipitation and evaporation is also essential in terms of meteorological drought impact on the development of successive drought stages, i.e. soil drought, agricultural and hydrological drought. Unlike precipitation based assessment, climatic water balance can weaken or strengthen drought evaluation through the incorporation of essential additional information about moisture conditions.

Climatic water balance is calculated as the difference between precipitation total and the reference evapotranspiration total in a particular period:

$$
C W B=P-E T_{o}
$$

where: $C W B$ - climatic water balance in a given period [mm], $P$ - precipitation in a given period [mm], $E T_{o}-$ reference evapotranspiration in a given period $[\mathrm{mm}]$ calculated using the Penman-Monteith method.

Similar to SPI, standardised climatic water balance $(S C W B)$ is also used. It is a standardised deviation of climatic water balance values in a given period from the 
median long-term value of this period (Łabędzki, Bąk 2004; Łabędzki 2006; Wibig 2012). It is calculated using the normalization method which normalises the historical time series of climatic water balance. Next, the standardised value is calculated using the following formula:

$$
S C W B=\frac{C W B_{n}-\overline{C W B_{n}}}{d_{C W B_{n}}}
$$

where: $S C W B$ - standardised climatic water balance, $C W B_{n}$ - normalised time series of climatic water balance (mm), $\overline{C W B_{n}}$ - mean value of normalised time series of climatic water balance $[\mathrm{mm}], d_{C W B_{n}}-$ standard deviation from the normalised time series of climatic water balance [mm].

The 3-category classification as shown in Table 6 was used in the regional system of drought monitoring conducted by the Institute of Technology and Life Sciences (ITP) in the Kujawy region.

Table 6. Classification of meteorological drought according to standardised climatic water balance $(S C W B)$

\begin{tabular}{|c|c|}
\hline SCWB & Meteorological drought category \\
\hline 0.50 to -0.99 & normal \\
\hline-1.00 to -1.49 & moderate drought \\
\hline-1.50 to -1.99 & severe drought \\
\hline$\leq-2.00$ & extreme drought \\
\hline \multicolumn{2}{|c|}{ source: own study }
\end{tabular}

\section{Agricultural drought}

Agricultural drought is frequently described in terms of drought indices, which are convenient and relatively simple to use. An agricultural drought index should be based on crop water balance simulation modeling. Crop water simulation-based analysis of drought is necessary for the identification of agricultural drought because it accounts for evapotranspiration, soil water capacity, current soil moisture, water deficit and other parameters of the soil-plant-atmosphere continuum essential in drought development.

Many indices and methods have been developed and are used to identify and determine the intensity of agricultural drought (Vogt, Somma 2000; Boken et al. 2005). Index-based assessment of agricultural drought has been used in Poland within the conducted drought monitoring systems since 2005 . The indices and the soil-crop parameters are estimated through the use of different models, for example the CROPBALANCE model, which was developed at the Institute of Technology and Life Sciences (Łabędzki 2006; Łabędzki et al. 2008).
The following indices have been used.

1. Crop Drought Index $C D I$ is used to quantify agricultural drought intensity (Brunini et al. 2005; Narasimhan, Srinivasan 2005; Tian, Boken 2005; Łabędzki 2006). It indicates the reduction of evapotranspiration in relation to potential evapotranspiration due to soil water deficit and is calculated as:

$$
C D I=1-\frac{E T}{E T_{p}}
$$

where: $E T$ - actual evapotranspiration under soil water deficit [mm], $E T_{p}$ - potential evapotranspiration under sufficient soil moisture content [mm].

$C D I$ assumes the values within the range $\langle 0,1\rangle$ :

$C D I=0$ when $E T=E T_{\mathrm{p}}$

$C D I<1$ when $E T<E T_{\text {p }}$

$C D I=1$ when $E T=0$

The actual and potential evapotranspiration is calculated using reference evapotranspiration and the crop and water stress coefficient approach and also the methodology described by Allen et al. (1998).

The actual evapotranspiration is calculated in ten-day periods, months and whole growing seasons as a sum of daily values. Evapotranspiration $E T^{t}$ in a day $t$ is calculated as:

$$
E T^{t}=k_{s}^{t} k_{c}^{t} E T_{0}^{t}
$$

where:

$E T_{0}^{t}$ - reference evapotranspiration in a day $t$, according to the Penman-Monteith equation (Allen et al. 1998) $\left[\mathrm{mm} \cdot \mathrm{d}^{-1}\right]$;

$k_{c}^{t}-$ crop coefficient (dimensionless);

$k_{s}^{t}$ - water stress coefficient (dimensionless).

Under excellent soil water conditions $k_{s}^{t}=1$ and

$$
E T^{t}=E T_{p}^{t}=k_{c}^{t} E T_{0}^{t}
$$

where:

$E T_{p}^{t}$ is potential evapotranspiration in a day $t\left[\mathrm{~mm} \cdot \mathrm{d}^{-1}\right]$.

Reference evapotranspiration incorporates the effect of weather conditions on evapotranspiration. Crop coefficient $k_{c}^{t}$ predicts evapotranspiration under standard conditions, i.e. under excellent agronomic and soil water conditions. The effect of soil water stress on crop evapotranspiration is described by reducing the value of the crop coefficient, and then multiplying it by the water stress coefficient $k_{s}^{t}$. The water stress coefficient is calculated as: 


$$
k_{s}^{t}=\frac{A S W_{p}^{\prime}}{(1-p) T A S W_{r}}
$$

where:

$A S W_{p}^{t}$ - available soil water in the root zone at the beginning of a day $t[\mathrm{~mm}]$;

$T A S W_{r}$ - total available soil water in the root zone [mm]; $p$ - soil water depletion fraction, fraction of $T A S W_{r}$ that a crop can extract from the root zone without suffering water stress (dimensionless), according to Allen et al. (1998).

Total available soil water $T A S W$ is calculated in $10-\mathrm{cm}$ layers as the difference between the water content at field capacity $(\mathrm{pF}=2.0)$ and wilting point $(\mathrm{pF}=4.2)$, using the formula:

$$
T A S W=S W C_{p f 2.0}-S W C_{p F 4.2}
$$

where:

$S W C_{p \rho 2.0}$ and $S W C_{p F 4.2}$ - the soil water content [in $\left.\mathrm{mm}\right]$ at $p F=2.0$ and $p F=4.2$;

$T A S W_{r}$ - is calculated in the root zone, changing in time according to the root depth $d$.

The estimation of water stress coefficient $k_{s}^{t}$ requires a daily water balance computation for the root zone. It is calculated as:

$$
A S W_{p}^{t}=A S W_{k}^{t-1}=A S W_{p}^{t-1}+P^{t-1}-E T^{t-1}
$$

where:

$A S W_{k}^{t-1}, A S W_{p}^{t-1}$ - available soil water in the root zone at the end and at the beginning of a day $t-1[\mathrm{~mm}]$;

$P^{t-1}-$ precipitation in a day $t-1[\mathrm{~mm}]$;

$E T^{t-1}$ - evapotranspiration in a day $t-1[\mathrm{~mm}]$.

This simple procedure assumes that the infiltration of daily precipitation to the root zone is within the same day, as well as that the time of deep percolation from the root zone when soil water content exceeds field capacity is also 1 day.

To categorise and evaluate the severity of drought, $C D I$ should be compared with the limits of different classes of drought. There is no unique, commonly acceptable classification of agricultural drought according to $C D I$. The three-category drought classification is used (moderate, severe, and extreme drought), with the threshold value for

Table 7. Classification of agricultural drought according to $C D I$

\begin{tabular}{|c|c|}
\hline Agricultural drought category & $C D I$ \\
\hline Moderate drought & $0.10 \div 0.19$ \\
\hline Severe drought & $0.20 \div 0.49$ \\
\hline Extreme drought & $0.50 \div 1.00$ \\
\hline
\end{tabular}

source: own study the moderate drought category equal to $C D I=0.1$ (Tab. 7). This means that a $10 \%$ reduction of evapotranspiration in relation to potential evapotranspiration is not considered as a drought effect.

2. Soil Moisture Index SMI is used to evaluate soil moisture conditions and to quantify soil drought intensity. It is calculated as (Hunt et al. 2009):

$$
S M I=-5+10 \frac{A S W_{a}}{T A S W}
$$

where:

$A S W_{a}$ - actual available soil water [mm],

$T A S W$ - total available soil water [mm].

This method is based on the assumption that evapotranspiration becomes limited below the midpoint between field capacity and wilting point, or at $50 \%$ of total available water. No reduction in $E T$ occurs until soil water falls below $50 \%$ of field capacity. Below $50 \%$ of field capacity the reduction in $E T$ is linear below $50 \%$ of field capacity.

The four-category classification of soil moisture conditions is used and two categories of soil drought are distinguished within it (moderate and severe drought), with the threshold value for soil drought equal to $S M I=0.00$ (Tab. 8).

Table 8. Classification of soil moisture according to SMI index

\begin{tabular}{|c|c|}
\hline Soil drought category & SMI \\
\hline No drought - excessive moisture & $\geq 5.00$ \\
\hline No drought - optimal moisture & {$[0.00 ; 5.00)$} \\
\hline Moderate drought & {$[-2.00 ; 0.00)$} \\
\hline Severe drought & {$[-5.00 ;-2.00]$} \\
\hline
\end{tabular}

source: own study

3. Crop Yield Reduction $Y R$ is used to quantify the effect of water stress and agricultural drought on a crop and is calculated from the equation (Raes 2004; Raes et al. 2006):

$$
Y R=\left(1-\frac{Y_{r e}}{Y_{p}}\right)=1-\prod_{i=1}^{N}\left[\prod_{j=1}^{M}\left(1-k_{y}\left(1-\frac{E T}{E T_{p}}\right)\right)^{\frac{\Delta t}{L_{i}}}\right]
$$

where: $Y_{r e}-$ actual yield reduced due to water stress, $Y_{p}-$ potential yield that can be expected under the given growing conditions for non-limiting water conditions, $k_{Y}$-yield response factor, $E T$ - actual evapotranspiration under soil water deficit, $E T_{p}$ - potential evapotranspiration under non-limiting water conditions, $N$ - total number of growth stages, $M-$ number of time steps with length $\Delta t_{j}$ (days) 
during the growth stage $i, \Delta t_{j}-$ the length of the period $j$ in the growth stage $i$ (days), $L_{i}$ - the total length of the growth stage $i$ (days), $j$ - the number of the period in the growth stage $i$.

Table 9. Classification of agricultural drought according to yield reduction $Y R$

\begin{tabular}{|c|c|}
\hline Agricultural drought category & YR $[\%]$ \\
\hline No drought - small yield loss & {$[0 ; 10)$} \\
\hline Moderate drought - moderate yield loss & {$[10 ; 20)$} \\
\hline Severe drought - heavy yield loss & {$[20 ; 50)$} \\
\hline Extreme drought - very heavy yield loss & {$[50 ; 100]$} \\
\hline \multicolumn{2}{|c}{ source: own study }
\end{tabular}

The three-category drought classification is used (moderate, severe, and extreme drought), with the threshold value for the moderate drought category equal to $Y R=0.1$ (Tab. 9). This means that a $10 \%$ reduction of crop yield in relation to potential yield is not considered as a drought effect.

\section{Drought monitoring systems in Poland}

Four different drought monitoring systems have been in operation in Poland since 2005. The Institute of Meteorology and Water Management (IMGW) conducts the system called "POSUCH@". The Institute of Soil Science and Plant Cultivation conducts the agricultural drought monitoring system. The Institute of Technology and Life Sciences (ITP) has developed two systems: the regional drought monitoring system in the Kujawy region and the nationwide system of monitoring and forecasting water deficit and surplus in agriculture.

Hydrometeorological drought monitoring and prediction system "POSUCH@". The system is conducted by the Institute of Meteorology and Water Management - National Research Institute IMGW-PIB (Tokarczyk, Szalińska 2013; IMGW 2014). The main objective of the system was to create a comprehensive, multipurpose application for drought hazard assessment supporting the operational work of hydrological forecasts offices. Operational drought hazard assessment includes meteorological and hydrological drought detection, analysis of drought intensity, duration and extension, as well as assessment of susceptibility to drought and drought hazard prediction. The data come from the measurements of meteorological and hydrological conditions, available within the monitoring network operated by IMGW-PIB. Its historical climatological database contains information from 350 meteorological stations and 1680 precipitation stations (with daily data from 333 stations) while its historical hydrological database contains data from 900 gauge stations with records of daily discharges from around $30 \%$ of the stations. Operational data are obtained from the network of meteorological and hydrological stations supplied with telemetry facilities.

A scheme of drought hazard assessment includes the following components: estimation of meteorological drought indices, evaluation of susceptibility to drought, drought hazard assessment, and generation of products. Two meteorological drought indices are used for the system of drought hazard assessment and prediction: EDI (effective drought index) - meteorological drought detection, intensity and duration analysis, temporal variability presentations, hazard evaluation; and SPI (standardised precipitation index) - mapping spatial distribution of meteorological drought, inferring regional susceptibility to drought. The system does not deal with agricultural drought. The resulting products of the system are presented on the website http://posucha.imgw.pl/.

Agricultural Drought Monitoring System (ADMS). The ADMS for Poland is provided by the Institute of Soil Science and Plant Cultivation - State Research Institute (IUNG-PIB) on behalf of the Ministry of Agriculture and Rural Development (Doroszewski et al. 2008, 2012; ADMS 2014). ADMS supports the fulfillment of an insurance policy established by the Polish Government, according to the Act of 7 July 2005 on subsidies to the insurance of agricultural crops and farm animals (Dz. U No. 150 , item 1249, 2006, No. 120, item 825). ADMS is designed to identify areas where there are crop losses caused by drought conditions, which are listed in the "Act on subsidies to insurance of agricultural crops and farm animals".

In the Agricultural Drought Monitoring System, meteorological conditions that cause droughts are evaluated by the climatic water balance $(C W B)$. The $C W B$ Index expresses the difference between the precipitation and potential evapotranspiration calculated with the Penman equation.

In the system, drought is defined by losses in crop yields caused by the occurrence of climatic water balance $(C W B)$ in the 6 consecutive ten-day periods below a defined value for an individual species or group of cultivated plants, as well as the soil category in the period from 1 April to 30 September. In determining the areas affected by a drought, besides the value of climatic water balance, the characteristics of soil retention are determined by soil category, and are identified based on soil and agricultural maps. In this way, a strong diversification of the susceptibility of Polish soil cover to the effects of a shortage of 
water is taken into account. Spatial differentiation of soil cover in Poland according to a susceptibility of different categories of soil to drought comprises the categories: a very light soil (very susceptible), light soil (susceptible), medium-heavy soil (medium susceptible), heavy soil (less susceptible).

The appearance of a specified value of $C W B$ causes on average a $20 \%$ reduction in the yield - this relates to the value of the long-term average. Critical values of the climatic water balance mean the appearance of drought for plant species or groups of cultivation plants and soil categories and periods of development.

A table with critical values of $C W B$ and monitoring results are presented on the website http://www.susza.iung. pulawy.pl/en/.

The "Monitoring meteorological and agricultural drought in Kujawy region" system. The system was developed and operated by the Kujawsko-Pomorski Research Centre of the Institute of Technology and Life Sciences in 2008-2012, in the Kujawy region of central Poland (Fig. 1). The region is the driest region in Poland, where periods of short or long-term drought are very common. The results of the monitoring of meteorological and agricultural drought were presented on the ITP website.

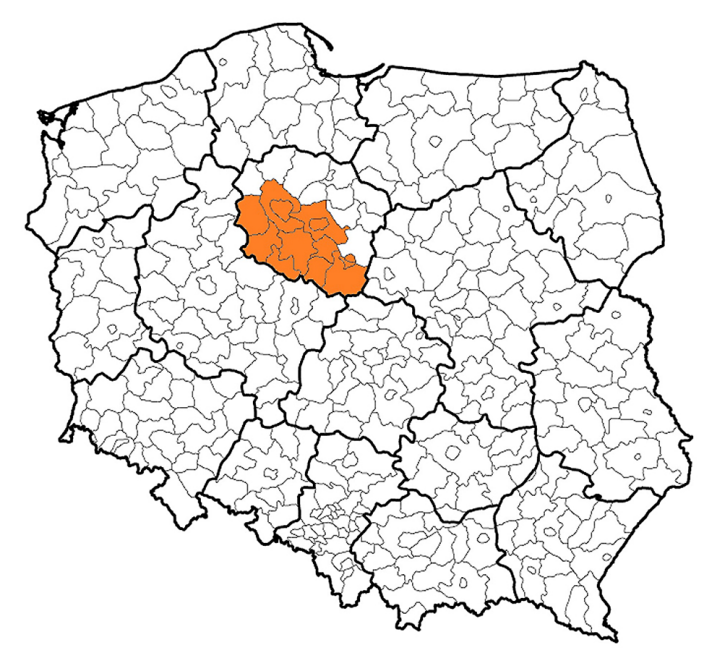

Fig. 1. Location of Kujawy region

Drought monitoring was carried out using the network of automatic stations for measuring agrometeorological and agrohydrological elements (Fig. 2).

Meteorological drought was monitored using the relative precipitation index $(R P I)$, the standardised precipitation index $(S P I)$ and the standardised climatic water balance $(S C W B)$. Agricultural drought monitoring was carried out using the crop drought index $(C D I)$.

Examples of monitoring results, which were presented every 10 days on the website, are shown in Tables 10 and 11.

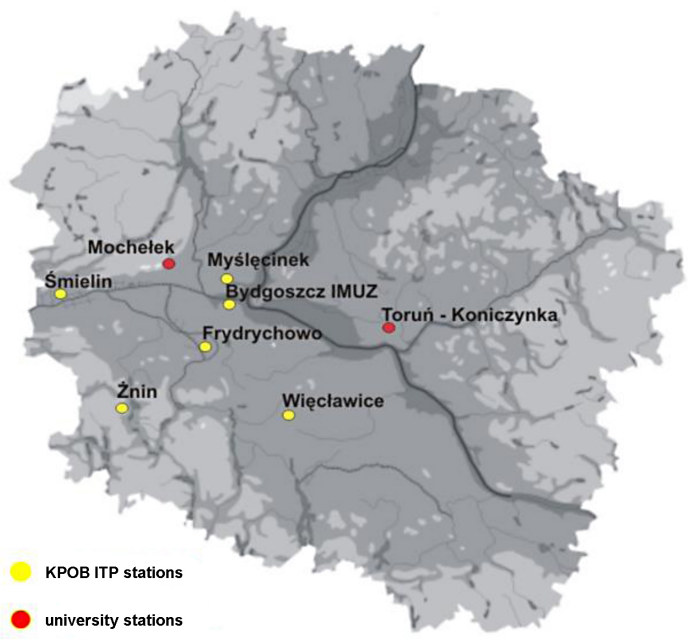

Fig. 2. Location of measurement stations

The monitoring helped to estimate the spatial variability of drought intensity. Using this information and meteorological forecasts, the progress of drought was predicted. The monitoring and estimation of drought supported decision-making and activities in agricultural production, water management in the rural areas, irrigation and natural resource protection in river valleys used agriculturally. Since 2012 the regional system has been included in the nationwide system of monitoring water deficit and surplus in agriculture.

Table 10. Meteorological drought intensity in 2009

\begin{tabular}{|c|c|c|c|c|c|}
\hline & \multirow{2}{*}{ Period } & \multirow{2}{*}{$\begin{array}{c}\text { PWB } \\
{[\mathrm{mm}]}\end{array}$} & \multicolumn{3}{|c|}{$\begin{array}{c}\text { Drought intensity } \\
\text { according to }\end{array}$} \\
\cline { 4 - 6 } & & & $R P I$ & SPI & SCWB \\
\hline $01.04-30.04$ & 31 & -30 & & & \\
\hline $11.04-10.05$ & 38 & -35 & & & \\
\hline $21.04-20.05$ & 47 & -38 & & & \\
\hline $01.05-31.05$ & 50 & -49 & & & \\
\hline $11.05-10.06$ & 50 & -59 & & & \\
\hline $21.05-20.06$ & 52 & -61 & & & \\
\hline $01.06-30.06$ & 58 & -54 & & & \\
\hline $11.06-10.07$ & 66 & -45 & & & \\
\hline $21.06-20.07$ & 76 & -36 & & & \\
\hline $01.07-31.07$ & 82 & -32 & & & \\
\hline $11.07-10.08$ & 77 & -33 & & & \\
\hline $21.07-20.08$ & 67 & -36 & & & \\
\hline $01.08-31.08$ & 62 & -30 & & & \\
\hline $11.08-10.09$ & 57 & -23 & & & \\
\hline $21.08-20.09$ & 53 & -15 & & & \\
\hline $01.09-30.09$ & 43 & -11 & & & \\
\hline$P-76$ & & & & \\
\hline
\end{tabular}

$P$ - mean precipitation in 1945-2008; $C W B$ - mean climatic water balance in $1945-2008$

\begin{tabular}{|l|l|l|l|}
\hline extreme drought & & moderate drought \\
\hline & severe drought & & no drought \\
\hline
\end{tabular}


Table 11. Agricultural drought intensity in 2009

\begin{tabular}{|c|c|c|c|c|c|c|c|}
\hline \multirow{2}{*}{ Period } & \multirow{2}{*}{$T A S W$} & \multirow{2}{*}{$\begin{array}{c}\text { Meteorological drought intensity } \\
\text { according to SPI }\end{array}$} & \multicolumn{2}{|c|}{ Root crops } & \multicolumn{3}{|c|}{ Grassland sites } \\
\hline & & & late potatoes & sugar beet & wet & drying & dry \\
\hline \multirow{2}{*}{ IV-V } & $120 \mathrm{~mm}$ & & & & \multirow{2}{*}{ - } & \multirow{2}{*}{ - } & \\
\hline & $200 \mathrm{~mm}$ & & & & & & \\
\hline \multirow{2}{*}{ IV-VI } & $120 \mathrm{~mm}$ & & & & \multirow{2}{*}{ - } & & \\
\hline & $200 \mathrm{~mm}$ & & & & & & \\
\hline \multirow{2}{*}{ IV-VII } & $120 \mathrm{~mm}$ & & & & & & \\
\hline & $200 \mathrm{~mm}$ & & & & & & \\
\hline \multirow{2}{*}{ IV-VIII } & $120 \mathrm{~mm}$ & & & & & & \\
\hline & $200 \mathrm{~mm}$ & & & & & & \\
\hline \multirow{2}{*}{ IV-IX } & $120 \mathrm{~mm}$ & & & & & & \\
\hline & $200 \mathrm{~mm}$ & & & & & & \\
\hline
\end{tabular}

TASW - available soil water; - no significant relationship between meteorological and agricultural drought; explanation see Table 10

The "Monitoring and forecasting water deficit and surplus in agriculture" system. Since 2012 Institute of Technology and Life Sciences has led national agrometeorological monitoring in rural areas (ITP 2014). The project is financed by the Polish Ministry of Agriculture and the Rural Development Programme: The Monitoring and Prediction of Progress and Risk of Water Deficit and Surplus in Rural Areas, 2011-2015. The system has been developed using the experiences gathered during the operation of the regional drought monitoring system for the Kujawy Region in Poland. The present nationwide system provides current and forecast evaluation of water deficit and surplus for agriculture in selected representative agricultural ecosystems and estimates potential reduction of crop yield due to water shortage. Required meteorological data are provided by a network of automatic stations located in 13 regions on Polish territory. Weather forecasts, necessary for the development of predictions of water deficit or surplus in a subsequent 10- and 20-day period, come from the meteorological service of MeteoGroup Poland.

Monitoring of water deficit and surplus and their consequences is carried out using an indicator method. Precipitation conditions are monitored using the standardised precipitation index SPI; soil moisture is monitored with the soil moisture index $S M I$; the deficit of water for crops with the agricultural drought index $C D I$; and the potential reduction of final yield with the yield reduction ratio $Y R$.

The SPI is calculated on the basis of precipitation data from 35 meteorological stations (Fig. 3). at 1-, 2-, 3-, 6-, 12-, 24-, 36- and 48-month time scales, and for the 30/31day periods moved every 10 days by 10 days. Using the forecast precipitation for the forthcoming 10 and 20 days the predictions of the 30-day SPI are created.

Soil moisture (soil moisture index $S M I$ ), deficit of water for crops (agricultural drought index $C D I$ ) and potential yield reduction $(Y R)$ are evaluated every 10/11 days for the previous 10/11 days and forecast for the next 10 and 20 days. The assessment is done in 13 regions distinguished on the basis of diversity of climate and agro-climatic conditions in Poland (Fig. 4). The total area of the selected region under monitoring is $204000 \mathrm{~km}^{2}$.

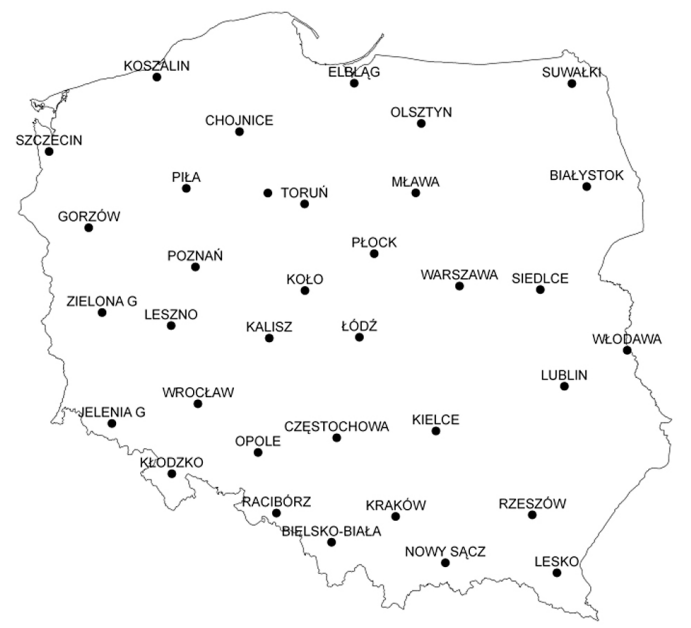

Fig. 3. Location of meteorological stations in Poland for which the $S P I$ is calculated

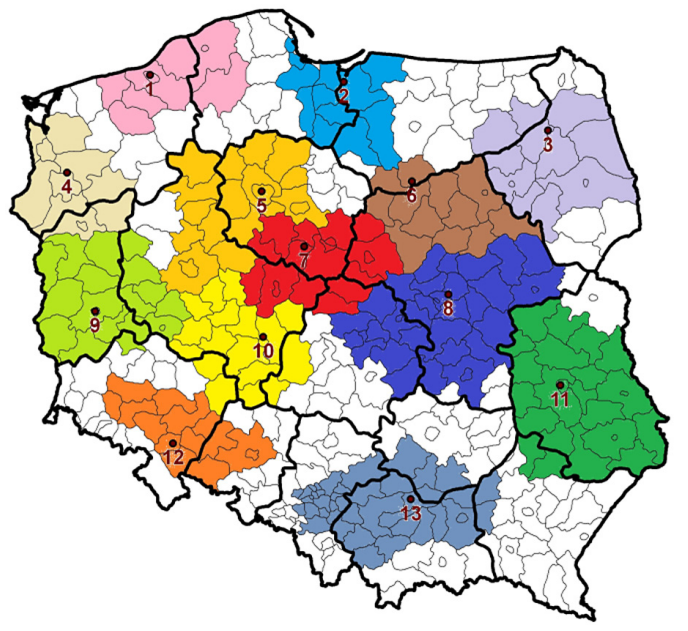

Fig. 4. Selected agricultural regions in Poland and meteorological stations 
Table 12. Comparison of the currently operating monitoring systems in Poland

\begin{tabular}{|c|c|c|c|c|c|c|}
\hline System & $\begin{array}{l}\text { Conducting } \\
\text { institution }\end{array}$ & $\begin{array}{l}\text { Monitored } \\
\text { area }\end{array}$ & $\begin{array}{l}\text { Monitored } \\
\text { drought type }\end{array}$ & Indices used & $\begin{array}{l}\text { Monitored } \\
\text { period/ } \\
\text { frequency }\end{array}$ & Forecast \\
\hline \multirow[b]{2}{*}{ POSUCH@ } & \multirow{2}{*}{$\begin{array}{l}\text { Institute of } \\
\text { Meteorology } \\
\text { and Water } \\
\text { Management }\end{array}$} & \multirow[b]{2}{*}{$\begin{array}{l}\text { whole country } \\
\left(312000 \mathrm{~km}^{2}\right)\end{array}$} & \multirow[b]{2}{*}{ meteorological } & $\begin{array}{c}E D I \\
\text { (Effective Drought Index) }\end{array}$ & $\begin{array}{l}365 \text { days/ } \\
1 \text { day }\end{array}$ & 3 days \\
\hline & & & & $\begin{array}{c}\text { SPI } \\
\text { (Standardised Precipitation } \\
\text { Index) }\end{array}$ & $\begin{array}{l}1 \text { month/ } \\
1 \text { month }\end{array}$ & - \\
\hline $\begin{array}{l}\text { Agricultural } \\
\text { Drought } \\
\text { Monitoring } \\
\text { System }\end{array}$ & $\begin{array}{l}\text { Institute of Soil } \\
\text { Science and } \\
\text { Plant } \\
\text { Cultivation }\end{array}$ & $\begin{array}{l}\text { whole country } \\
\left(312000 \mathrm{~km}^{2}\right)\end{array}$ & agricultural & $\begin{array}{c}C W B \\
\text { (Climatic Water Balance) }\end{array}$ & $\begin{array}{l}60 \text { days/ } \\
10 \text { days }\end{array}$ & - \\
\hline \multirow{5}{*}{$\begin{array}{l}\text { Monitoring } \\
\text { and forecasting } \\
\text { water deficit } \\
\text { and surplus in } \\
\text { agriculture }\end{array}$} & \multirow{5}{*}{$\begin{array}{l}\text { Institute of } \\
\text { Technology } \\
\text { and Life } \\
\text { Sciences }\end{array}$} & \multirow{5}{*}{$204000 \mathrm{~km}^{2}$} & \multirow[t]{2}{*}{ meteorological } & $\begin{array}{c}\text { SPI } \\
\text { (Standardised Precipitation } \\
\text { Index) }\end{array}$ & $\begin{array}{l}1,2,3,6, \\
12,24,36, \\
48 \text { months/ } \\
1 \text { month }\end{array}$ & - \\
\hline & & & & $\begin{array}{c}\text { SPI } \\
\text { (Standardised Precipitation } \\
\text { Index) }\end{array}$ & $\begin{array}{l}30 \text { days/ } \\
10 \text { days }\end{array}$ & 10 and 20 days \\
\hline & & & soil & $\begin{array}{c}\text { SMI } \\
\text { (Soil Moisture Index) }\end{array}$ & $\begin{array}{l}10 \text { days/ } \\
10 \text { days }\end{array}$ & 10 and 20 days \\
\hline & & & \multirow{2}{*}{ agricultural } & $\begin{array}{c}C D I \\
\text { (Crop Drought Index) }\end{array}$ & $\begin{array}{l}10 \text { days/ } \\
10 \text { days }\end{array}$ & 10 and 20 days \\
\hline & & & & $\begin{array}{c}Y R \\
\text { (Yield Reduction) }\end{array}$ & $\begin{array}{l}10 \text { days/ } \\
10 \text { days }\end{array}$ & 10 and 20 days \\
\hline
\end{tabular}

The results of the monitoring and forecasts are presented as tables and maps on the Internet at www.agrometeo. itp.edu.pl.

Among all operating agrometeorological monitoring systems in Poland, the nationwide system of monitoring and forecasting water deficit and surplus created by researchers from ITP is distinctive from other operating systems by supplying a broader range of information, including precipitation and soil moisture conditions, agricultural drought intensity and potential crop yield reduction as a final effect of agricultural drought. Moreover the system has enhanced the module of medium- and long-term forecasting.

A summary of the monitoring systems currently in operation is given in Table 12. It contains information on the area being monitored, the types of monitored drought, the drought indices used in the systems, the monitored periods and the frequency with which it is updated. Two systems give forecasts of the indices and of drought intensity.

\section{Summary and concluding remarks}

In this article, a brief review is presented on the definition of meteorological and agricultural droughts, common drought indices and the operational systems for monitoring droughts in Poland.
Drought is a widespread and frequent disaster. This climate anomaly becomes very characteristic in many countries within humid climate zones. Droughts can be divided into meteorological, hydrological, agricultural, and socioeconomic varieties. Meteorological drought is the result of deficiencies in precipitation. Hydrological drought is associated with the effects of precipitation deficit on surface or subsurface water resources. Agricultural drought is the effect of various characteristics of meteorological and hydrological drought in agriculture, comprising a reduction in evapotranspiration, soil water deficits, and reduced crop yield.

Drought indicators are the common measures for drought assessment. They should provide a concise overall measure of the phenomena on the basis of available and easily measured hydro-climatic, soil and crop data. The paper contains an inventory of drought measures (indicators) that are applied to evaluate meteorological and agricultural drought in Poland. Nowadays in Poland no one uniform system of drought assessment exists. The presented systems give information for the whole country or for a specific region but they are directed to some specific drought analyses. They play a complementary role. The preference for particular methods and indices for drought monitoring depends on the particular application. For meteorological drought monitoring, the recently 
developed standardised precipitation index SPI is preferable. This index has a multiple time-scale capability and various other advantages compared to the other indices. It is recommended by the World Meteorological Organization. For agricultural drought monitoring SPI should be combined with real-time monitoring of soil moisture deficit, crop water stress and the evaluation of possible crop yield reduction. For this aim different methods and indices are applied in the presented systems. Some of them have gained wide acceptance across Europe and the wider world (SMI, CDI, and $Y R$, according to Raes). The method used in the Agricultural Drought Monitoring System for Poland (ADMS), based on the relationships between climatic water balance and crop yield reduction, has more of a regional applicability.

The information supplied by the existing drought monitoring systems can support decision-making and activities aimed at the mitigation of the negative impacts of droughts, effective use of water resources, irrigation scheduling and other human activities that are connected with the climate.

\section{Bibliography}

ADMS, 2014, Agricultural Drought Monitoring System in Poland, www.susza.iung.pulawy.pl. (access date: 15.03.2014)

Agnew C.T., 2000, Using the SPI to identify drought, Drought Network News, 12, 6-11

Alfonso do Ó., 2005, Regional drought analysis and mitigation using the SPI, Proceedings of 21st ICID Conference, 15-19 May 2005, Frankfurt-Słubice, Germany-Poland, CD-ROM

Allen R.G., Pereira L.S., Raes D., Smith M., 1998, Crop evapotranspiration - Guidelines for computing crop water requirements, FAO Irrigation and Drainage Paper No. 56, FAO, Rome

Boken V.K., Cracknell A.P., Heathcote R.L. (eds.), 2005, Monitoring and predicting agricultural drought, Oxford University Press, 472 pp.

Bonaccorso B., Bordi I., Cancielliere A., Rossi G., Sutera A., 2003, Spatial variability of drought: an analysis of the SPI in Sicily, Water Resources Management, 17 (4), 273-296, DOI: 10.1023/A:1024716530289

Brunini O., Dias Da Silva P.L., Grimm A.M., Assad Delgado E., Boken V.K., 2005, Agricultural drought phenomena in Latin America with focus on Brazil, [in:] Monitoring and predicting agricultural drought, V.K. Boken, A.P. Cracknell, R.L. Heathcote (eds.), Oxford University Press, 156-168

Doroszewski A., Jadczyszyn J., Kozyra J., Pudełko R., Stuczyński T., Mizak K., Łopatka A., Koza P., Górski T., Wróblewska E., 2012, Podstawy systemu monitoringu suszy rolniczej, Woda-Środowisko-Obszary Wiejskie, 12 (2), 77-91
Doroszewski A., Kozyra J., Pudełko R., Stuczyński T., Jadczyszyn J., Koza P., Łopatka A., 2008, Monitoring suszy rolniczej w Polsce, Wiadomości Melioracyjne i Łąkarskie, $1,35-38$

Hunt E.D., Hubbard K.D., Wilhite D.A., Arkebauer T.M., Dutcher A.L., 2009, The development and evaluation of a soil moisture index, International Journal of Climatology, 29 (5), 747-759, DOI: $10.1002 /$ joc. 1749

IMGW, 2014, Drought monitoring system “POSUCH@”, http:// posucha.imgw.pl. (access date: 15.03 2014)

ITP, 2014, System "Monitoring and forecasting water deficit and surplus in agriculture", http://agrometeo.itp.edu.pl, (access date: 15.03 2014)

Kaczorowska Z., 1962, Opady w Polsce w przekroju wieloletnim, Prace Geograficzne, 33, Polska Akademia Nauk, 109 pp.

Lloyd-Hughes B., Saunders M.A., 2002, A drought climatology for Europe, International Journal of Climatology, 22 (13), 1571-1592, DOI: 10.1002/joc.846

Łabędzki L., 2006, Susze rolnicze - zarys problematyki oraz metody monitorowania i klasyfikacji, Woda-Środowisko-Obszary Wiejskie, Rozprawy Naukowe i Monografie, 17, 107 pp.

Łabędzki L., 2007, Estimation of local drought frequency in central Poland using the standardized precipitation index SPI, Irrigation and Drainage, 56 (1), 67-77, DOI: 10.1002/ird.285

Łabędzki L., Bąk B., 2004, Standaryzowany klimatyczny bilans wodny jako wskaźnik suszy, Acta Agrophysica, 3 (1), 117-124

Łabędzki L., Bąk B., Kanecka-Geszke E., Kasperska-Wołowicz W., Smarzyńska K., 2008, Związek między suszą meteorologiczną i rolniczą w różnych regionach agroklimatycznych Polski, Woda-Środowisko-Obszary Wiejskie, Rozprawy Naukowe i Monografie, 25, 137 pp.

McKee T.B., Doesken N.J., Kleist J., 1993, The relationship of drought frequency and duration to time scales, Proceedings of the $8 \mathrm{t}^{\mathrm{h}}$ Conference of Applied Climatology, 17-22 January, Anaheim, California, 179-184

McKee T.B., Doesken N.J., Kleist J., 1995, Drought monitoring with multiple time scales, Preprints of the $9^{\text {th }}$ Conference of Applied Climatology, 15-20, Dallas, Texas, 233-236

Narasimhan B., Srinivasan R., 2005, Development and evaluation of soil moisture deficit index (SMDI) and evapotranspiration deficit index (ETDI) for agricultural drought monitoring, Agricultural and Forest Meteorology, 133 (1-4), 69-88, DOI: 10.1016/j.agrformet.2005.07.012

Paulo A.A., Pereira L.S., 2006, Drought Concepts and Characterization. Comparing Drought Indices Applied at Local and Regional Scales, Water International, 31 (1), 37-49, DOI: 10.1080/02508060608691913

Paulo A.A., Pereira L.S., Matias P.G., 2002, Analysis of the regional droughts in southern Portugal using the theory of runs and the standardized precipitation index, Proceedings of International Conference of ICID on Drought Mitigation and 
Prevention of Land Desertification, Bled, Slovenia, April 2125, Lubljana, CD-ROM

Pereira L.S., Cordery I., Iacovides I., 2002, Coping with water scarcity, UNESCO IHP VI, Technical Documents in Hydrology, 58, $269 \mathrm{pp}$.

Raes D., 2004, BUDGET - a soil water and salt balance model. Reference Manual, Version 6.0, http://www.iupware.be (access date: 4.11.2013)

Raes D., Geerts S., Kipkorir E., Wellens J., Sahli A., 2006, Simulation of yield decline as a result of water stress with a robust soil water balance model, Agricultural Water Management, 81 (3), 335-357, DOI: 10.1016/j.agwat.2005.04.006

Szalai S., Szinell C.S., 2000, Comparison of two drought indices for drought monitoring in Hungary - a case study, [in:] Drought and drought mitigation in Europe, J.V. Vogt, F. Somma (eds.), Dordrecht: Kluwer Academic Publisher, 161-166

Szalai S., Szinell C.S., Zoboki J., 2000, Drought monitoring in Hungary, [in:] Early warning systems for drought preparedness and drought management, Proceedings of an Expert Group Meeting, 5-7 September, WMO, Lisbon, Portugal, 182-199

Tian G., Boken V.K., 2005, Monitoring agricultural drought in China, [in:] Monitoring and predicting agricultural drought, V.K. Boken, A.P. Cracknell, R.L. Heathcote (eds.), Oxford University Press, 354-368
Tokarczyk T., Szalińska W., 2013, The operational drought hazard assessment scheme - performance and preliminary results, Archives of Environmental Protection, 39 (3), 61-77, DOI: 10.2478/aep-2013-0028

Tomaszewska T., 1994, Susze atmosferyczne na przestrzeni ostatniego czterdziestolecia, XXV Zjazd Agrometeorologów, Olsztyn - Mierki, 27-29 wrzesień, ART Olsztyn, 169-178

Tsakiris G., Vangelis H., 2004, Towards a drought watch system based on spatial SPI, Water Resources Management, 18 (1), 1-12, DOI: 10.1023/B:WARM.0000015410.47014.a4

U.S. National Drought Mitigation Center, 2014, http://drought. unl.edu/ (access date: 15.03. 2014)

Vermes L., 1998, How to work out a drought mitigation strategy. An ICID Guide, DVWK Guidelines for water management, 309, 29 pp.

Vermes L., Fesus I., Nemes C., Palfai I., Szalai S., 2000, Status and progress of the national drought mitigation strategy in Hungary, Proceedings of Workshop on Drought Mitigation in Central and East Europe, Budapest, 12-15 April, 55-64

Vogt J.V., Somma F. (eds.), 2000, Drought and drought mitigation in Europe, Dordrecht: Kluwer Academic Publisher, 325 pp.

Wibig J., 2012, Warunki wilgotnościowe w Polsce w świetle wskaźnika standaryzowanego klimatycznego bilansu wodnego, Woda-Środowisko-Obszary Wiejskie, 12 (2), 329-340 
